\title{
Çeltik Üreticilerinin Katıldıkları Tarımsal Yayım Yöntemlerinin Sürdürülebilir Tarım Algılama Düzeylerine Göre Değerlendirilmesi
}

\author{
Buse AVKIRAN*1, Hasan YILMAZ ${ }^{1}$
}

\begin{abstract}
Öz
$\mathrm{Bu}$ araştırmada, Edirne ili İpsala ilçesinde çeltik üreticilerinin katıldıkları tarımsal yayım yöntemlerinin sürdürülebilir tarım algılama düzeylerine göre değerlendirilmesi amaçlanmıştır. Çalışmanın materyalini, oransal örnekleme yöntemi ile belirlenen 89 işletmeden anket ile toplanan orijinal nitelikli veriler oluşturmuştur. Lojistik regresyon analizi sonuçlarına göre; üreticilerin sürdürülebilir tarım algılamalarının orta ve yüksek düzeyde olma olasılığı ile tarla günlerine katılım, ilçe tarım personeli ile görüşme, tarımsal danışmanlık hizmetinden faydalanma, konferans-panel etkinliklerine katılım ve televizyonda tarımsal program izleme değişkenleri arasında istatistiki olarak önemli bir ilişki bulunmuştur. Araştırma bölgesinde, çeltik üretiminde eğitim ve yayım programları geliştirilirken, bireysel yayım yöntemlerinin yanında, grup yayım yöntemlerine katılımı artırmak için çalışmalar yapılmalıdır.
\end{abstract}

Anahtar Kelimeler: Çeltik üreticileri, Sürdürülebilirlik, Tarımsal yayım

\section{Evaluation of Agricultural Extension Methods Participated by Paddy Farmers According to Their Sustainable Agriculture Perception Levels}

\begin{abstract}
In this research, it was aimed to evaluate the agricultural extension methods participated by paddy farmers according to their sustainable agriculture perception levels in Ipsala district of Edirne province. The main material of the study consisted of original data collected through questionnaires from 89 farms determined by the proportional sampling method. According to the results of logistic regression analysis; a statistically significant relationship was found between the likelihood of farmers' perception of sustainable agriculture is at a medium or high level and the variables of attending field days, meeting with personnel's of the agriculture directorate, using agricultural advice services, attending conference panel events and watching agricultural programs on television. For developing training and extension programs for farmers in paddy production in the research region, studies should be conducted to increase participation in group extension methods as well as individual extension methods.
\end{abstract}

Keywords: Paddy farmers, Sustainability, Agricultural extension

ORCID ID (Yazar sirasina göre)

0000-0001-9511-0074, 0000-0002-0487-8449

\footnotetext{
Yayın Kuruluna Geliş Tarihi: 11.11.2021

Kabul Tarihi: 29.12.2021

${ }^{1}$ Isparta Uygulamalı Bilimler Üniversitesi, Ziraat Fakültesi, Tarım Ekonomisi Bölümü, Isparta

*E-posta: buseavkran@gmail.com
} 


\section{Çeltik Üreticilerinin Katıldıkları Tarımsal Yayım Yöntemlerinin Sürdürülebilir Tarım Algılama Düzeylerine Göre Değerlendirilmesi}

\section{Giriş}

Türkiye ekonomisinde tarım oldukça önemli bir role sahiptir (Torun ve Taluğ, 2005; Yalçın ve Boz, 2007). Tarımda gelişme, teknolojik yeniliklerin üreticiler tarafından kullanılmasının yaygınlaştırılmasıyla mümkün olabilmektedir (Özçatalbaş, 1992; Boz ve ark., 2004).

Tarım teknolojilerinin üretici kitlesine tanıtılması ve benimsetilmesi için tarımsal yayım çalışmalarına temel görevler düşmektedir. Tarımsal yayımın amacı halkın yaşam koşullarını iyileştirmektir. Tarımsal yayım, insanlara yaşadıkları koşullarda ihtiyaçlarını, problemlerini belirlemeyi, bu belirlenen ihtiyaçlar ve problemlerle başa çıkabilmek için gerekli olan bilgileri elde etmeyi ve faaliyete geçebilmeleri için motive etmeyi öğretir (Taluğ ve Tatlıdil, 1993; Bostan Budak, 1999; Akkaya, 2002; Çelik Ateş ve Terin, 2008 ).

Tarımsal yayım, üreticilerin sürdürülebilir tarım tekniklerinden haberdar olmaları, benimsemeleri ve kabul etmeleri için anahtar rol oynamaktadır. Sürdürülebilir tarımla uğraşan veya uğraşmak isteyen üreticiler öncelikle sürdürülebilir tarım ile ilgili bilgilere ve eğitim programlarına ihtiyaç duymakta ve doğal olarak yayım elemanlarından ihtiyaç duydukları bu bilgiler için talepte bulunacaklardır. Sürdürülebilir tarım tekniklerini benimsemek isteyen üreticilere araştırma sonuçlarının, eğitim ve bilgi kaynaklarının kullanım için hazır hale getirilmesi üreticilerin bu kavramı benimsenmesinde en etkili yoldur (Bostan Budak, 1999).

Sürdürülebilir tarım, uzun dönemde doğal kaynakların korunmasının yanında çevreye zarar vermeyen tarımsal teknolojilerin kullanıldığ tarımsal yapının oluşturulmasını ifade etmektedir. Sürdürülebilir tarım; bir yandan tarımda verimliliği korurken diğer yandan çevreye verilen zararı azaltarak, kısa ve uzun dönemde ekonomiyi canlı tutmak, tarımla uğraşanların yaşam kalitesini yükselterek bu Formülde;

$\mathrm{n}=$ Örnek hacmini yöndeki uygulamaları geliştirmektir (Turhan, 2005). Sürdürülebilir tarım, dünyanın kaynaklarını tüketmeden, çevre dostu uygulamalar ile doğanın ilkelerini takip ederek bitkisel ve hayvansal üretim yapan, ekonomik, teknik, ekolojik, politik, etik ve sosyal boyutlar olan bir tarımsal üretim biçimidir. Sürdürülebilir tarımsal uygulamaların yaygınlaştırılması, sürdürülebilir tarım tekniklerinin benimsetilmesi sürecinde yayım elamanlarının kullandıkları ve üreticilerin katıldıkları tarımsal yayım yöntemleri önem arz etmektedir (Yilmaz ve ark., 2016; Y1lmaz, 2018).

Bu araştırmada Türkiye'de çeltik üretiminde önemli bir yere sahip olan Edirne ilinin İpsala ilçesinde, çeltik üretimi yapan üreticilerin katıldıkları tarımsal yayım yöntemlerinin sürdürülebilir tarım algılama düzeylerine göre değerlendirilmesi amaçlanmıştır.

\section{Materyal ve Yöntem}

Araştırmanın ana materyalini, Edirne ili İpsala ilçesine bağlı köylerde çeltik üretimi yapan, oransal örnekleme yöntemiyle seçilen 89 tarım işletmesinden anket yoluyla elde edilen birincil veriler oluşturmuştur. Anketler 2019 yılında yapılmış olup, anket verileri 2018 y1lı üretim dönemi bilgilerini kapsamaktadır.

Anket yapılacak köylerin seçimi; Tarım ve Orman İlçe Müdürlüğü teknik elemanlarının görüşleri de alınarak, araştırmanın amacına uygun olarak, ilçeyi tarımsal yapı ve sosyo ekonomik bakımdan temsil edebilecek nitelikte 4 köy belirlenerek yapılmıştır. $\mathrm{Bu}$ amaçla belirlenen köylerde çeltik üretimi yapan üretici sayısı araştırmanın ana kitlesini oluşturmuştur. Anket uygulanacak örnek sayısının belirlenmesinde oransal örnekleme yöntemi kullanılmıştır (Miran, 2010).

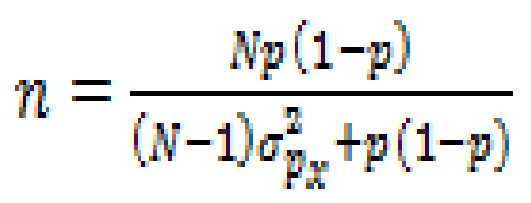

$\mathrm{N}=$ Popülasyon hacmini 


\section{Çeltik Üreticilerinin Katıldıkları Tarımsal Yayım Yöntemlerinin Sürdürülebilir Tarım Algılama Düzeylerine Göre Değerlendirilmesi}

$\mathrm{p}=$ Tahmin oranı (maksimum örnek hacmi için $0.05)$

$\boldsymbol{\sigma}_{p_{x}}^{2}=$ Ana kitle varyansını ifade etmektedir.

Eşitlik (1) kullanılarak ana kitleyi temsil edebilecek örnek sayısı 89 olarak hesaplanmıştır. Anket uygulanacak işletmeler tesadüfen seçilmiştir. Çeltik üreticileri sürdürülebilir tarım algılamalarına yönelik iki gruba ayrılarak incelenmiştir.

Çiftçilerin sürdürülebilir tarım teknolojilerini benimsemeleri ve uygulamaları konusunda ikna edilmeleri için öncelikle tarımsal teknolojileri takip edip uygulamaları hem de gelecek nesillerin ihtiyaçlarını karşılamaları, kırsal çevreyi korumaları, istikrarlı ve uzun vadeli gelir için hayati öneme sahip olduğuna inanmaları gerekmektedir. Sürdürülebilirlikte algılanan önem çiftçiden çiftçiye farklılık göstermektedir ve çifçilerin sosyo-ekonomik özelliklerinden ve bilgi arama davranışlarından etkilendiğini göstermektedir (Hayran vd., 2018). Bu nedenle, çiftçilerin sürdürülebilir tarım hakkındaki algılarını araştırmak ve bu algıları etkileyen faktörleri incelemek sürdürülebilir tarımsal kalkınma için yayım programları tasarlamak ve ortak geleceği güvence altına almak açısından önem arz etmektedir.

Üreticilerin sürdürülebilir tarım uygulamalarına yönelik algılamaları, çeltik üreticilerinin sürdürülebilir tarım algılamalarını ölçmeye çalışan 60 maddelik ve 5 puanlık likert tipi ölçeğe verdikleri yanıtların toplanmasıyla hesaplanmıştır.

Tüm maddeler için ortalama; Tamamen katılmiyorum $(\mathrm{TKM})=1.00-1.49$, Kat1lmiyorum $(\mathrm{KM})=1.50-2.49$, Orta düzeyde kat1lıyorum $(\mathrm{ODK})=2.50-3.49$, Kat1liyorum $(\mathrm{K})=3.50-4.49$, Tamamen katıliyorum $=(\mathrm{TK})=4.50-5.00$. şeklinde sinıflandırılmıştır.
Çeltik üreticilerinin sürdürülebilir tarım alg1 düzeyi, ortalamadan aradaki sapma aralığ kullanılarak aşağıdaki gibi sınıflandırılmıştır:

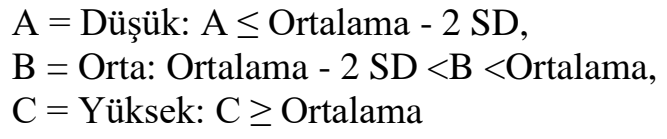

$\mathrm{A}=$ Düşük: $\mathrm{A} \leq$ Ortalama $-2 \mathrm{SD}$,

$\mathrm{B}=$ Orta: Ortalama $-2 \mathrm{SD}<\mathrm{B}<$ Ortalama,

$\mathrm{C}=$ Yüksek: $\mathrm{C} \geq$ Ortalama

$\mathrm{Bu}$ araştırmada çeltik üreticilerinin sürdürülebilir tarımı algılama düzeylerine göre; üreticilerin bilgi arama ve iletişim davranışları ile çeltik üretiminde katıldıkları tarımsal yayım yöntemleri arasındaki ilişkiyi belirlemek amaciyla lojistik regresyon analizi kullanılmıştır (Hair ve ark., 1994; Kalayc1, 2008; Alpar, 2011; Hayran ve Gül, 2018).

\section{Bulgular ve Tartışma \\ Çeltik Üreticilerinin Sürdürülebilir Tarımı Algılama Düzeyleri}

Çizelge 1'de çeltik üreticilerinin sürdürülebilir tarımı algılama düzeyleri verilmiştir. Çeltik üreticilerinin sürdürülebilir tarım uygulamalarına yönelik algılamalarını ölçmeye çalışan 60 maddelik 5 puanlık likert tipi ölçeğe dayanarak; katılmıyorum (KM) kategorisine 5 madde, orta düzeyde katıliyorum (ODK) kategorisine 6 madde, kat1lyorum (K) kategorisine 12 madde, tamamen kat1liyorum (TK) kategorisine 37 madde yerleştirilmiştir. Çeltik üreticilerinin sürdürülebilir tarımı algilama düzeylerinin ölçülmesi sonucunda; \%41.57'inin orta düzeyde, \%58.43'ünün yüksek düzeyde sürdürülebilir tarım algılamasına sahip olduğu ortaya konmuştur. Düşük düzeyde sürdürülebilir tarım algilamasına sahip üreticiler kategorisinde hiçbir üretici yer almamıştır. Singha ve Mishra (2015) üreticilerin \%19.73'ünün yüksek, $\% 63.82$ 'sinin orta ve \%16.45'inin düşük düzeyde sürdürülebilirlik algısına sahip olduğu sonucuna ulaşmışlardır. 


\section{Çeltik Üreticilerinin Katıldıkları Tarımsal Yayım Yöntemlerinin Sürdürülebilir Tarım Algılama Düzeylerine Göre Değerlendirilmesi}

\begin{tabular}{|c|c|c|c|c|}
\hline Sinıflandirma & $\begin{array}{c}\text { Algilama } \\
\text { Seviyesi }\end{array}$ & $\begin{array}{l}\text { Endeks } \\
\text { Değeri }\end{array}$ & $\begin{array}{c}\text { Kişi } \\
\text { sayis1 }\end{array}$ & $\begin{array}{l}\text { Oran } \\
(\%)\end{array}$ \\
\hline Endeks Değeri < Ortalama - 2SD & Düşük (A) & 1.57 'nin altında & 0 & 0 \\
\hline $\begin{array}{l}\text { Ortalama - } 2 \text { SD } \leq \text { Endeks Değeri }< \\
\text { Ortalama }\end{array}$ & Orta (B) & $1.57-4.32$ & 37 & 41.57 \\
\hline Endeks Değeri $\geq$ Ortalama & Yüksek (C) & 4.33 ve üstü & 52 & 58.43 \\
\hline Toplam Hane & & & 89 & 100.00 \\
\hline
\end{tabular}

\section{Çeltik Üreticilerinin Sosyo-Ekonomik Özellikleri}

Araştırmada çeltik üreticilerinin sürdürülebilir tarımı algılama düzeylerine göre sosyoekonomik nitelikleri ortaya konmuştur (Çizelge 2). Çeltik üreticilerinin yaş ortalamasının 48.03 y1l olduğu saptanmıştır. Yüksek düzeyde sürdürülebilir tarım algılamasına sahip üreticilerin orta düzeyde sürdürülebilir tarım algılamasına sahip üreticilere göre, daha genç olduğu tespit edilmiştir (47.63 yıl). Türkiye'nin değişik bölgelerinde yapılan başka çalışmalarda üreticilerin ortalama yaş1 50.89 yıl (Yilmaz ve ark. 2009), 47 y1l (Atış ve ark.,2004), 50.50 yıl (Türer, 2019) olarak bulunmuştur.

Çeltik üreticilerinin ortalama 9.03 y1l eğitim aldıkları belirlenmiştir. Ortalama eğitim düzeyi yüksek düzeyde sürdürülebilir tarım algılamasına sahip üreticilerde daha yüksektir (9.44 y1). Yapılan farklı çalı̧̧alarda üreticilerin ortalama 6.4 yıl (Aydın Eryılmaz ve Kılıç, 2019), 7.85 yıl (Hayran ve ark., 2018) ve 6.82 yıl (Yılmaz ve ark., 2009) eğitim aldıkları ortaya konmuştur.

Daha genç olan ve eğitim seviyesi daha yüksek olan üreticilerin sürdürülebilir tarımı daha yüksek düzeyde algıladıklarını söylemek mümkündür.

Çeltik işletmelerinin aile genişliği incelendiğinde; ortalama 4.09 bireyden oluştuğu tespit edilmiştir. Yüksek düzeyde sürdürülebilirlik algısına sahip olan üreticilerin, ortalama aile birey sayısının daha fazla olduğu saptanmıştır (4.21 kişi). Yapılan farklı çalışmalarda da çiftçilerin üreticilerin ortalama aile genişliğinin 4.70 kiși (Saltan, 2006), 5 kiși (Atış ve ark., 2004), 6 kişi (Öz, 2019) ve 6.25 kişi (Türer, 2019) olduğu belirlenmiştir.
Araştırmada çeltik üreticilerinin ortalama 46.17 yıldır köyde ikamet ettikleri ortaya konmuştur. Orta düzeyde sürdürülebilir tarım algılamasına sahip üreticilerin, köyde ortalama ikametgâh süresinin yüksek düzeyde sürdürülebilir tarım algılamasına sahip üreticilere göre daha yüksek olduğu tespit edilmiştir (48.62 y11).

Çeltik üreticilerinin ortalama 26.78 y1llık tarımsal deneyime sahip olduğu belirlenmiştir. Orta düzeyde sürdürülebilir tarım algılamasına sahip üreticilerin ortalama tarımsal deneyiminin, yüksek düzeyde sürdürülebilir tarım algılamasına sahip üreticilere göre daha yüksek olduğu tespit edilmiştir (27.62 y1l). Yapılan farklı çalışmalarda da üreticilerin mesleki deneyim ortalamasının yaklaşı 28 yıl (Şimşek ve Armağan, 2020), 25 yıl (Çolak Kudal, 2019), 29 y1l (Thanh ve ark., 2015) olduğu hesaplanmıştır.

Araştırmada çeltik üreticilerinin çeltik tarıminda deneyiminin ortalama 21.45 y1l olduğu belirlenmiştir. Orta düzeyde sürdürülebilir tarım algılamasına sahip üreticilerin yüksek düzeyde sürdürülebilir tarım algılamasına sahip üreticilere göre, ortalama çeltik tarımında deneyim süresinin daha yüksek olduğu tespit edilmiştir (23 yıl). Türkiye'de yapılan farklı bir çalışmada üreticilerin çeltik tarımında deneyiminin ortalama 15 yıl olduğu bildirilmiştir (Aydoğan, 2018).

Köyde daha uzun y1llar ikamet eden, ortalama tarımsal deneyimi ve çeltik tarımında deneyimi daha yüksek olan üreticilerin sürdürülebilir tarımı daha düşük düzeyde algıladıklarını söylemek mümkündür. 


\section{Çeltik Üreticilerinin Katıldıkları Tarımsal Yayım Yöntemlerinin Sürdürülebilir Tarım Algılama Düzeylerine Göre Değerlendirilmesi}

Çeltik üreticilerinin ortalama işletme arazisi genişliği 308 dekardır. Yüksek düzeyde sürdürülebilir tarım algılamasına sahip üreticilerin, ortalama işletme arazisi genişliğinin orta düzeyde sürdürülebilir tarım algılamasına sahip üreticilere göre daha yüksek olduğunu söylemek mümkündür (378.06 dekar). Farklı bir çalışmada üreticilerin ortalama işletme arazisi genişliğinin 142 dekar olduğu hesaplanmıştır (Yurdakoş, 2009).

Araştırmada çeltik üreticilerinin ortalama çeltik arazisi genişliği 270.20 dekar olarak tespit edilmiştir. Yüksek düzeyde sürdürülebilir tarım algılamasına sahip üreticilerin ortalama çeltik arazisi genişliğinin orta düzeyde sürdürülebilir tarım algılamasına sahip üreticilere göre, daha yüksek olduğu belirlenmiştir (354.31 dekar). Yapılan farklı bir çalışmada çeltik üreticilerinin ortalama 236.95 dekar alanda çeltik üretimi yaptığı bildirilmiştir (Türer, 2019).

Çeltik üreticilerinin ortalama yıllık tarımsal gelirinin 668302 TL ve ortalama y1llık çeltik gelirinin 644487 TL olduğu belirlenmiştir. Yüksek düzeyde sürdürülebilir tarım algilamasına sahip üreticilerin, ortalama yıllık tarımsal gelirinin $(877459)$ ve ortalama y1llık çeltik gelirinin (852 309 TL) orta düzeyde sürdürülebilir tarım algılamasına sahip üreticilere göre, daha yüksek olduğu ortaya konmuştur.

Çizelge 2. Çeltik üreticilerinin sosyo-ekonomik özellikleri

\begin{tabular}{|c|c|c|c|c|c|c|}
\hline \multirow[t]{2}{*}{ Özellikler } & \multicolumn{2}{|c|}{$\begin{array}{c}\text { Orta Düzeyde } \\
\text { Sürdürülebilir Tarım } \\
\text { Algılamasına Sahip } \\
\text { Üreticiler }\end{array}$} & \multicolumn{2}{|c|}{$\begin{array}{c}\text { Yüksek Düzeyde } \\
\text { Sürdürülebilir Tarım } \\
\text { Algilamasına Sahip } \\
\text { Üreticiler }\end{array}$} & \multicolumn{2}{|c|}{ Genel } \\
\hline & Ortalama & $\begin{array}{c}\text { Standart } \\
\text { Sapma }\end{array}$ & Ortalama & $\begin{array}{c}\text { Standart } \\
\text { Sapma }\end{array}$ & Ortalama & $\begin{array}{c}\text { Standart } \\
\text { Sapma }\end{array}$ \\
\hline Üreticinin yaş1 & 48.59 & 11.94 & 47.63 & 10.40 & 48.03 & 11.08 \\
\hline Eğitim durumu (Y1l) & 8.46 & 3.44 & 9.44 & 3.31 & 9.03 & 3.40 \\
\hline Aile büyüklüğü (Adet) & 3.92 & 1.19 & 4.21 & 1.17 & 4.09 & 1.19 \\
\hline Köyde ikametgâh süresi (Y1l) & 48.62 & 11.97 & 44.42 & 13.88 & 46.17 & 13.28 \\
\hline Tarımsal deneyimi (Y1l) & 27.62 & 13.78 & 26.17 & 11.48 & 26.78 & 12.51 \\
\hline Çeltik tarımında deneyimi (Y1l) & 23.00 & 12.32 & 20.35 & 9.10 & 21.45 & 10.64 \\
\hline İ̀sletme arazisi genişliği (Dekar) & 209.54 & 174.48 & 378.06 & 721.02 & 308.00 & 568.60 \\
\hline Çeltik arazisi genişliği (Dekar) & 152.00 & 128.45 & 354.31 & 724.86 & 270.20 & 569.03 \\
\hline Yillık tarımsal geliri (TL) & 374353 & 345595 & 877459 & 1741625 & 668302 & 1372361 \\
\hline Y1llık çeltik geliri (TL) & 352413 & 345430 & 852309 & 1748803 & 644487 & 1377383 \\
\hline
\end{tabular}

Çeltik Üreticilerinin Bilgi Arama ve İletişim Davranışları ile Katıldıkları Tarımsal Yayım Yöntemleri

Tarımsal üretimin gerçekleştirilmesinde; birim alandan en fazla ürün alınması, insan sağlığının göz ardı edilmemesi ve tarımsal sürdürülebilirlik gibi konularda gerekli özenin gösterilmesi büyük önem arz etmektedir. $\mathrm{Bu}$ ise üreticilere yönelik gerçekleștirilecek yayım çalışmaları ile mümkün olabilmektedir. Tarımsal yayım, kırsal kalkınmayı sağlayan en önemli etkenlerden birisidir (Yurdakoş, 2009).
Bireysel yayımda, doğrudan bir kişiye yönelik olarak yapılan yayım hizmetleri söz konusudur (Şentürk, 2013). Grup yayım, ortak sorunlara sahip olan üreticilerden oluşan gruplara yönelik yapılan eğitim şeklidir (Kayabaş, 2016). Kitle yayım en hızlı ve ucuz olan yayım yöntemidir. Yayım elemanlarının az olduğu durumlarda daha geçerli bir eğitim sistemidir. Üreticileri tarımsal yenilikten haberdar etme konusunda etkinliği oldukça yüksektir (Șentürk, 2013; Kayabaş, 2016).

Çeltik üreticilerinin sürdürülebilir tarımı algılama düzeylerine göre tarımsal yayım 


\section{Çeltik Üreticilerinin Katıldıkları Tarımsal Yayım Yöntemlerinin Sürdürülebilir Tarım Algılama Düzeylerine Göre Değerlendirilmesi}

yöntemlerinden yararlanma durumları Çizelge 3 'te sunulmuştur. Üreticilerin en çok iletişim kurduğu yayım elemanları arasında ziraat odası personelinin (\%84.27) bulunduğu tespit edilmiştir. Üreticilerin \%83.15'i Tarım ve Orman İl/İlçe Müdürlüğü personeli ile iletişim kurmakta, \%44.94'ü tarım danışmanı ile görüşmekte ve \%12.36's1 çiftlik ziyaretlerine katılım sağlamaktadır. Orta düzeyde sürdürülebilir tarım algılamasına sahip üreticilerin en çok ziraat odası personeli (\%81.08) ile iletişim kurduğu; yüksek düzeyde sürdürülebilirlik algılamasına sahip üreticilerin ise en çok Tarım ve Orman İl/İlçe Müdürlüğü personeli (\%96.15) ile iletişim kurduğu saptanmıştır. Yapılan farklı çalışmalarda, üreticilerin en çok iletişim kurduğu yayım elamanları arasında; tarım danışmanının (\%94) (Kayabaş, 2016) ve Tarım il/ilçe Müdürlüğü elemanlarının (\%81) (Derman, 2010) ilk sirada yer aldıkları belirtilmektedir.

Çeltik üreticilerinin grup yayım yöntemlerine katılımları incelendiğinde; üreticilerin \%84.27'sinin tarla günlerine katılım sağladığını söylemek mümkündür. Üreticilerin \%69.66's1 konferans panel etkinliklerine, \%61.80'i tarımsal amaçlı gezilere, \%59.55'i kurs-seminer etkinliklerine, \%58.43'ü çiftçi eğitim toplantılarına ve \%51.69'u demonstrasyon etkinliklerine katılım sağlamaktadır. Grup yayım yöntemleri arasında demonstrasyon etkinliği dışında kalan diğer grup yayım yöntemlerine yüksek düzeyde sürdürülebilir tarım algilamasına sahip üreticiler daha fazla düzeyde katılım sağlamaktadır. Türkiye'de yapılan farklı çalışmalarda üreticilerin \%47.80'inin demonstrasyon etkinliklerine katıldığ1 (Kızılaslan ve Ünal, 2013), \%83.33'ünün tarımsal konularla ilgili toplantılara ve eğitim çalışmalarına katıldığı (Kizilaslan, 2009) ve \%89'nun tarla günlerine katıldığ1 (Şentürk, 2013) ifade edilmiştir.

Çeltik üreticilerinin kitle yayım yöntemlerinden biri olan fuar-sergi etkinliklerine katılımının (\%92.13) en yüksek olduğu tespit edilmiştir. Üreticilerin \%87.64'ünün TV'de tarımsal amaçlı program izlediği, \%85.39'unun tarımla ilgili yazılı materyalleri okuduğu, \%26.97'sinin radyoda tarımsal amaçlı programları dinlediği saptanmıştır. Çeltik üreticilerinin \%98.88'inin cep telefonu kullandığ 1 \% \%89.77'sinin tarımsal amaçlı telefon ya da SMS yoluyla bilgilendirme aldığ $1, \% 74.16$ 'sının interneti kullandığ 1 ve interneti kullanan üreticilerin \%90.91'inin interneti tarımsal amaçlı kullandığı tespit edilmiştir.

Yüksek düzeyde sürdürülebilir tarım algilamasına sahip üreticilerin fuar sergi etkinliklerine katılımının (\%94.23), televizyonda tarımsal amaçlı program izleme durumunun (\%90.38), dokunmatik telefon kullanımının (\%82.35), tarımsal amaçlı telefon ya da SMS yoluyla bilgilendirme alma durumunun (\%90.20) ve internet kullanımının (\%82.69) orta düzeyde sürdürülebilir tarım algılamasına sahip üreticilere göre, daha yüksek olduğu saptanmıştır.

Orta düzeyde sürdürülebilir tarım algılamasına sahip üreticilerin ise tarmla ilgili kitap, dergi, gazete, broşür vb. materyalleri okuma durumunun (\%86.49), radyoda tarımsal amaçlı program dinleme durumunun (\%27.03), tuşlu cep telefonu kullanım durumunun $(\% 32.43)$ ve interneti tarımsal amaçlı kullanım durumunun (\%95.65) yüksek düzeyde sürdürülebilir tarım algilamasına sahip üreticilere göre, daha yüksek olduğu tespit edilmiştir.

Kayabaş (2016), üreticilerin \%98'inin cep telefonu kullandığını, \%54'ünün internet kullandığını ifade etmiştir. Kızılaslan ve Ünal (2013), üreticilerin \%94'ünün TV'de tarımsal amaçlı program izlediğini, \%58.20'sinin tarımsal amaçlı telefon ya da SMS yoluyla bilgilendirme aldığını, \%31.30'unun radyoda tarımsal amaçlı program dinlediğini, \%28.40'ının interneti tarımsal amaçlı kullandığını, \%58.20'sinin tarımla ilgili yazılı kaynakları okuduğunu belirtmişlerdir. Şentürk (2013), üreticilerin \%44.80'inin internet/bilgisayar kullandığını, Çolak Kudal (2019), \%94'ünün tarımsal program izlediğini, $\% 72$ 'sinin tarımsal gazete okuduğunu, Erdal ve Çallı (2014), \%52.38'inin bilgisayar ve internet kullandığını tespit etmişlerdir. 


\section{Çeltik Üreticilerinin Katıldıkları Tarımsal Yayım Yöntemlerinin Sürdürülebilir Tarım Algılama Düzeylerine Göre Değerlendirilmesi}

Çizelge 3. Tarımsal yayım yöntemleri

\begin{tabular}{|c|c|c|c|c|c|c|}
\hline \multirow[t]{2}{*}{ Tarımsal Yayım Yöntemleri } & \multicolumn{2}{|c|}{$\begin{array}{c}\text { Orta Düzeyde } \\
\text { Sürdürülebilir } \\
\text { Tarım Algılamasına } \\
\text { Sahip Üreticiler }\end{array}$} & \multicolumn{2}{|c|}{$\begin{array}{l}\text { Yüksek Düzeyde } \\
\text { Sürdürülebilir } \\
\text { Tarım Algılamasına } \\
\text { Sahip Üreticiler }\end{array}$} & \multicolumn{2}{|c|}{ Genel } \\
\hline & $\begin{array}{c}\text { Say1 } \\
\text { (Oran) }\end{array}$ & $\begin{array}{l}\text { Oran } \\
(\%)\end{array}$ & $\begin{array}{c}\text { Say1 } \\
\text { (Adet) }\end{array}$ & $\begin{array}{c}\text { Oran } \\
(\%)\end{array}$ & $\begin{array}{l}\text { Say1 } \\
\text { (Adet) }\end{array}$ & $\begin{array}{l}\text { Oran } \\
(\%)\end{array}$ \\
\hline \multicolumn{7}{|l|}{ Bireysel Yayım Yöntemleri } \\
\hline Ziraat odası personeliyle görüşme & 30 & 81.08 & 45 & 86.54 & 75 & 84.27 \\
\hline $\begin{array}{l}\text { Tarım ve Orman İl/İlçe Müdürlüğü } \\
\text { personeliyle görüşme }\end{array}$ & 24 & 64.86 & 50 & 96.15 & 74 & 83.15 \\
\hline Tarım danışmanıyla görüşme & 11 & 29.73 & 29 & 55.77 & 40 & 44.94 \\
\hline Çiftlik ziyaretlerine katılım & 2 & 5.41 & 9 & 17.31 & 11 & 12.36 \\
\hline \multicolumn{7}{|l|}{ Grup Yayım Yöntemleri } \\
\hline Tarla günlerine katılım & 30 & 81.08 & 45 & 86.54 & 75 & 84.27 \\
\hline Konferans-panel etkinliklerine katılım & 21 & 56.76 & 41 & 78.85 & 62 & 69.66 \\
\hline Tarımsal amaçlı gezilere katılım & 19 & 51.35 & 36 & 69.23 & 55 & 61.80 \\
\hline Kurs-seminer etkinliklerine katılım & 19 & 51.35 & 34 & 65.38 & 53 & 59.55 \\
\hline Çiftçi eğitim toplantılarına katılım & 19 & 51.35 & 33 & 63.46 & 52 & 58.43 \\
\hline Demonstrasyon etkinliklerine katılım & 21 & 56.76 & 25 & 48.08 & 46 & 51.69 \\
\hline Tarımsal amaçlı yarışmalara katılma & 0 & 0.00 & 1 & 1.92 & 1 & 1.12 \\
\hline \multicolumn{7}{|l|}{ Kitle Yayım Yöntemleri } \\
\hline Fuar-sergi etkinliklerine katılım & 33 & 89.19 & 49 & 94.23 & 82 & 92.13 \\
\hline TV'de tarımsal amaçlı program izleme & 31 & 83.78 & 47 & 90.38 & 78 & 87.64 \\
\hline $\begin{array}{l}\text { Tarımla ilgili kitap, dergi, gazete, broşür vb. } \\
\text { materyaller okuma }\end{array}$ & 32 & 86.49 & 44 & 84.62 & 76 & 85.39 \\
\hline Radyoda tarımsal amaçlı program dinleme & 10 & 27.03 & 14 & 26.92 & 24 & 26.97 \\
\hline Cep telefonu kullanımı & 37 & 100.00 & 51 & 98.08 & 88 & 98.88 \\
\hline \multirow{2}{*}{ Kullanılan cep telefonu } & 12 & 32.43 & 9 & 17.65 & 21 & 23.86 \\
\hline & 25 & 67.57 & 42 & 82.35 & 67 & 76.14 \\
\hline $\begin{array}{l}\text { Tarımsal amaçlı telefon ya da SMS yoluyla } \\
\text { bilgilendirilme }\end{array}$ & 33 & 89.19 & 46 & 90.20 & 79 & 89.77 \\
\hline İnterneti kullanma & 23 & 62.16 & 43 & 82.69 & 66 & 74.16 \\
\hline İnterneti tarımsal amaçlı kullanma & 22 & 95.65 & 38 & 88.37 & 60 & 90.91 \\
\hline
\end{tabular}

* Birden fazla cevap olduğu için oranlar toplamı 100'den fazla çıkmıştır.

Çeltik Üreticilerinin Sürdürülebilir Tarımı Algılama Düzeyleri ile Katıldıkları Tarımsal Yayım Yöntemlerine İliş̧kin Logit Model Tahmin Sonuçları

Çeltik üreticilerinin sürdürülebilir tarım algılamaları ile bilgi arama davranışlarından; ilçe tarım müdürlüğü personeli ile görüşme, tarımsal danışmanlık hizmetinden yararlanma, tarla günlerine katılım, konferans-panel etkinliklerine katılım, televizyonda tarımsal program izleme, demonstrasyon etkinliklerine katılım, dokunmatik telefon kullanımı, tarımsal basılı materyalleri okuma, fuar-sergi etkinliklerine katılim ve kurs seminer etkinliklerine katılım açıklayıcı değişkenleri kullanılarak logit model tahmini yapılmıştır. Çeltik üreticilerinin sürdürülebilir tarım algılamalarının orta ve yüksek düzeyde olması ile katıldıkları tarımsal yayım yöntemleri (bilgi arama ve iletişim davranışları) arasındaki ilişkiyi ortaya koymak amacıyla yapılan lojistik regresyon analizi sonuçları Çizelge 4 'de verilmiştir.

Çeltik üreticilerinin orta ve yüksek düzeyde sürdürülebilir tarım algılamaları bağımlı 


\section{Çeltik Üreticilerinin Katıldıkları Tarımsal Yayım Yöntemlerinin Sürdürülebilir Tarım Algılama Düzeylerine Göre Değerlendirilmesi}

değişken olarak seçilmiştir. Sürdürülebilir tarım algılamasının orta veya yüksek düzeyde olma olasılığ 1 ile katıldıkları tarımsal yayım yöntemleri (bilgi arama ve iletişim davranışları) arasındaki ilişkiyi belirleyebilmek için modele 10 değişken dâhil edilerek istatistiki olarak test edilmiştir

Çeltik üreticilerinin sürdürülebilir tarımı algılama düzeyleri ile katıldıkları tarımsal yayım yöntemleri (bilgi arama ve iletişim davranışları) arasındaki ilişkiyi belirleyebilmek için kurulan ikili lojistik regresyon modelinin çözümlenmesi sonucu sabit terim başta olmak üzere; üreticilerin ilçe tarım personeli ile görüşme durumu, tarımsal danışmanlık hizmetinden yararlanma durumu, tarla günlerine katılımı, konferans-panel etkinliklerine katılımı, televizyonda tarımsal program izleme durumu değişkenleri istatistiksel olarak anlamlı bulunmuştur.
Üreticilerin ilçe tarım müdürlüğü personeli ile görüşme durumu, tarımsal danışmanlık hizmetinden yararlanma durumu, konferanspanel etkinliklerine katılımı, televizyonda tarımsal program izleme durumu arttıkça sürdürülebilir tarımı algılama düzeyi azalmakta, tarla günlerine katılımı arttıkça sürdürülebilir tarımı algılama düzeyi artmaktadır. Başka bir ifade ile ilçe tarım müdürlüğü personeli ile görüşme durumunun, tarımsal danışmanlık hizmetinden yararlanma durumunun, konferans panel etkinliklerine katılımının, televizyonda tarımsal program izleme durumunun artması üreticilerin sürdürülebilir tarım algılamalarının orta düzeyde olma olasılığını arttırmakta; tarla günlerine katılımının artması ise üreticilerin sürdürülebilir tarım algılamalarının yüksek düzeyde olma olasılığını artırmaktadır.

Çizelge 4. Lojistik regresyon analizi sonuçları

\begin{tabular}{|c|c|c|c|c|}
\hline Bağımsız Değişkenler & Katsay1 & $\begin{array}{c}\text { Wald } \\
\text { İstatistiği } \\
\end{array}$ & $\begin{array}{c}\text { Anlamlılık } \\
\text { Düzeyi }\end{array}$ & $\begin{array}{c}\text { Olasılık } \\
\text { Oranı }\end{array}$ \\
\hline İlçe tarım personeli ile görüşme & -4.879 & 12.700 & $* 0.000$ & 0.008 \\
\hline Tarımsal danışmanlık hizmetinden yararlanma & -1.656 & 6.786 & $* 0.009$ & 0.191 \\
\hline Tarla günlerine katılım & 3.398 & 3.990 & $* * 0.046$ & 29.898 \\
\hline Konferans-panel etkinliklerine katılım & -1.766 & 6.479 & $* 0.011$ & 0.171 \\
\hline Televizyonda tarımsal program izleme & -2.112 & 5.328 & $* * 0.021$ & 0.121 \\
\hline Demonstrasyon etkinliklerine katılım & 1.123 & 3.259 & 0.071 & 3.075 \\
\hline Dokunmatik telefon kullanımı & -1.270 & 3.356 & 0.067 & 0.281 \\
\hline Tarımsal materyalleri okuma & 1.209 & 2.201 & 0.138 & 3.351 \\
\hline Fuar-sergi etkinliklerine katılım & -2.955 & 2.285 & 0.131 & 0.052 \\
\hline Kurs, seminer etkinliklerine katılım & 1.029 & 2.429 & 0.119 & 2.797 \\
\hline Sabit sayı & 1.779 & 7.790 & 0.005 & 5.922 \\
\hline
\end{tabular}

\section{Sonuç ve Öneriler}

$\mathrm{Bu}$ araştırmada çeltik üretiminde önemli bir yere sahip olan Edirne ilinin İpsala ilçesinde, çeltik üretimi yapan üreticilerin katıldıkları tarımsal yayım yöntemleri (bilgi arama ve iletişim davranışları) sürdürülebilir tarımı algılama düzeylerine göre değerlendirilmiştir.

Lojistik regresyon analizi sonuçlarına göre; çeltik üreticilerinin sürdürülebilir tarım algılamalarının orta ve yüksek düzeyde olma olasılığı ile tarla günlerine katılım, ilçe tarım personeli ile görüşme, tarımsal danışmanlık hizmetinden faydalanma, konferans-panel etkinliklerine katılım ve televizyonda tarımsal program izleme değişkenleri arasında istatistiki olarak önemli bir ilişki bulunmuştur. Araştırma sonuçlarına göre çeltik üreticilerinin sürdürülebilir tarımı algılama düzeyleri ile tarımsal yayım yöntemlerinden tarla günlerine katılım arasında pozitif; ilçe tarım müdürlüğü personeli ile görüşme, tarımsal danışmanlık hizmetinden faydalanma, konferans-panel etkinliklerine katılım ve televizyonda tarımsal 


\section{Çeltik Üreticilerinin Katıldıkları Tarımsal Yayım Yöntemlerinin Sürdürülebilir Tarım Algılama Düzeylerine Göre Değerlendirilmesi}

program izleme değişkenleri arasında negatif bir ilişki olduğu saptanmıştır.

Günümüzde bilişim ve iletişim teknolojilerinin tarım sektöründe kullanımı artmış olsa da, araştırma bölgesinde sürdürülebilir tarım teknikleri konusunda çeltik üreticileri arasında bilgi ve yeniliklerden haberdar olmayan çok sayıda üretici olduğunu söylemek mümkündür.

$\mathrm{Bu}$ bağlamda, çiftçilerin sürdürülebilir tarım uygulamalarını arttırmaya yönelik yapılan çalışmalarda, sürdürülebilir tarımın ekonomik faydalarına ve çevreye duyarlı uygulamalarına odaklanmak, gelişen yeni teknolojiler hakkında daha fazla bilgi vermek önem arz etmektedir.

Araştırma bölgesinde sürdürülebilir tarım teknikleri hakkında tarımsal yayım ve danıșmanlık hizmetleri verilmeli ve bu hizmetlerin niteliği artırılmalıdır. Konferanspanel etkinliklerine katılımın arttırılması için yayım elemanları aracılığıyla daha çok çiftçiye ulaşılmalıdır. Üreticilerin sürdürülebilir tarım teknolojileri konusunda bilgi ve tecrübelerini arttırmak amaciyla kurs-seminer etkinliklerine katılımlarını teşvik edici çalışmalar yapılmalıdır. Sürdürülebilir tarımsal üretime yönelik programların televizyon kanallarında daha fazla yayınlanması için özendirici politikalar uygulanabilir.

Üreticilerin gelir ve yaşam standartlarının iyileştirilmesi, çevre dostu sürdürülebilir tarım tekniklerinin yaygınlaşması bilimsel nitelikteki bilgi ve teknolojinin üreticilere ulaştırılması ile sağlanabilecektir. $\mathrm{Bu}$ amaçla bireysel yayım yöntemlerinin yanında, daha çok sayıda üreticiye ulaşmak için deneyimli yayım elemanları ile uygulanacak grup yayım yöntemlerine katılımı arttırmak için çalışmalar yapılmalıdır.

\section{Teşekkür ve Beyan}

Çalışmayı destekleyen Isparta Uygulamalı Bilimler Üniversitesi Bilimsel Araştırma Projeleri Koordinasyon Birimi'ne (Proje No: 2019-YL-1-0024) teşekkür ederiz.
Bu çalışma "18-19 Eylül 2021 tarihlerinde gerçekleştirilen ISPEC 7th International Conference On Agriculture, Animal Sciences And Rural Development" konferansinda sözlü bildiri olarak sunulmuş ve bildiri kitabında tam metin olarak yayınlanmıştır.

\section{Kaynaklar}

Akkaya, M. S. (2002) Türkiye ve Avrupa Birliği'nde Tarımsal Yayım ve Haberleşmede Bilgi Akışı Üzerine Bir Araştırma. Yüksek Lisans Tezi, Atatürk Üniversitesi.

Alpar, R. (2011) Uygulamalı Çok Değişkenli Istatistiksel Yöntemler. 599-611, Detay Yayıncılık, Ankara.

Atış, E., Nurlu, E., Miran, B., Kenanoğlu, Z. (2004) Tarımsal Arazinin Sürdürülebilir Kullanımı Etkileyen Ekonomik ve Ekolojik Faktörler Üzerine Bir Araştırma. Ege Üniversitesi, 1997 ZRF014 no'lu Proje. ISBN:975-94133-1-0, Bornova-İzmir.

Aydın Eryılmaz, G., Kılıç, O. (2019) Çevre Koruma Amaçlı Tarımsal Eğitimlerin Çiftçi Davranışlarına Etkisi: Samsun İli Bafra İlçesi Örneği. Türkiye Tarımsal Araştırmalar Dergisi 6(3):336-341.

Aydoğan, M. (2018) Tarımsal Yenilik Sistemleri ve İş Birliği Ağları. Samsun İli Çeltik Üreticileri Örneği. Doktora Tezi, Ondokuz Mayıs Üniversitesi.

Bostan Budak, D. (1999) Sürdürülebilir Tarım ve Tarımsal Yayım. Tarım Ekonomisi Dergisi 5: 20-21.

Boz, İ., Akbay, C., Orhan, E., Candemir, S. (2004) Çiftçilerin Tarımsal Faaliyetlerde Kullandıkları Bilgi Kaynaklarının Belirlenmesi ve Tarımsal Yayım Açısından Değerlendirilmesi. Türkiye VI. Tarım Ekonomisi Kongresi, 16-18 Eylül 2004, 596-603, Tokat.

Çelik Ateş, H. Terin, M. (2008) Hayvancılığa Yönelik Yapılan Kalkınma ve Yayım Çalışmalarının Genel Bir Değerlendirmesi: Van İli Örneği. Uludă Üniversitesi Ziraat Fakültesi Dergisi 22(2): 7-16. 


\section{Çeltik Üreticilerinin Katıldıkları Tarımsal Yayım Yöntemlerinin Sürdürülebilir Tarım Algılama Düzeylerine Göre Değerlendirilmesi}

Çolak Kudal, G. (2019) Edirne İlinde Çeltik Destekleme Politikalarının İncelenmesi. Yüksek Lisans Tezi, Çanakkale Onsekiz Mart Üniversitesi.

Derman, A. (2010) Mardin İlinde Tarımsal Yayımı Geliştirme Projesi Kapsamında Görev Yapan Elemanların Tarımsal Yayım ve Danışmanlık Sistemine Bakışları. Yüksek Lisans Tezi, Çukurova Üniversitesi.

Erdal, G., Çallı, A. (2014) Çiftçilerin Bilgisayar ve İnternet Kullanımı Üzerine Bir Araştırma: Denizli İli Çivril Örneği. Gaziosmanpaşa Bilimsel Araştırma Dergisi 8:71-81.

Hair, F.J., Anderson, J.R., Tatham, R.Z., Black, W.C. (1994) Multivariate Data Analysis. 413-434, Third Edition, New York, USA.

Hayran, S., Gül, A. (2018) Mersin İlinde Çiftçilerin Tarımsal Kredi Kullanım Kararlarını Etkileyen Faktörler. I $\breve{g} d ı r$ Üniversitesi Fen Bilimleri Enstitüsü Dergisi 8(1):271-277.

Hayran, S., Gül, A., Sarıdaş, M. A. (2018) Farmers' Sustainable Agriculture Perception in Turkey: The Case of Mersin Province. New Medit 3:69-78.

Kalayc1 Ş. (2008) SPSS Uygulamalı Çok Değişkenli İstatistik Teknikleri. 62-78, Asil Yayın Dağılım, İstanbul.

Kayabaş, Z. (2016) İstanbul İli Silivri İlçesinde Tarımsal Üretim ve Yayım Yaklaşımlarının Analizi Üzerine Bir Araştırma. Yüksek Lisans Tezi, Namık Kemal Üniversitesi.

Kızılaslan, N. (2009) Çiftçilerin Tarımsal Yayım Konusundaki Tutum ve Davranışları, Tokat İli Yeşilyurt İlçesi Araștırmas1. Tük Bilim Araștırma Vakfi Bilim Dergisi 2(4):439-445.

Kızılaslan, N., Ünal, Y. (2013) Ciftçilerin Tarımsal Yayım Farkındalıklarının Belirlenmesi (Tokat/Erbaa Örneği). Gaziosmanpaşa Bilimsel Araştırma Dergisi 5:1-19.

Miran, B. (2010) Temel Istatistik. Ege Üniversitesi Basımevi, İzmir.

Öz, F. (2019) Çorum İli Çeltik Üreticilerinin İklim Değișikliği Algılamaları ve
Uyum Stratejilerini Etkileyen Faktörler. Yüksek Lisans Tezi, Ondokuz Mayıs Üniversitesi.

Özçatalbaş. O. (1992) GAP'ta Başarı Yolu: Tarımsal Yayım. Tarım ve Köyişleri Bakanlı̆̆ Tarım ve Köy Dergisi 76:2829.

Saltan, A. (2006) Adana İli Aladağ İlçesi Kökez Köyünün Sosyo-Ekonomik Yap1s1 ve Kalkınma Açısından Tarımsal Yayım Çalışmalarının Değerlendirilmesi. Yüksek Lisans Tezi, Çukurova Üniversitesi.

Singha, K., Mishra, S. (2015) Sustainability of Rice Cultivation: A Study of Manipur. Rice Research Open Access 4(1):1-4.

Şentürk, C. O. (2013) Çeltik Üretimi Yapan Tarım İşletmelerinde Tarımsal İlaç Kullanımında Yayım Yaklaşımları: Edirne İli Örneği. Yüksek Lisans Tezi, Namık Kemal Üniversitesi.

Şimşek, Y. B., Armağan, G. (2020) Tarımsal Yayım ve Danışmanlık Hizmetlerinde Algılanan Hizmet Kalitesi: Aydın İlinde Bir Uygulama. Organizasyon ve Yönetim Bilimleri Dergisi 12(2):150169.

Taluğ, C., Tatlıdil, H. (1993) Tarımsal Yayım ve Haberleşme. Ankara Üniversitesi Ziraat Fakültesi Ders Notu, Ankara.

Thanh, N. V., Sukprasert, P., Yapwattanaphun, C. (2015) Farmers' Sustainable Agriculture Perception in the Vietnam Uplands: the Case of Banana Farmers in Quang Tri Province. Research Journal of Applied Sciences, Engineering and Technology 10(8):960-967.

Torun, E., Taluğ, C. (2005) Çay Budama Projesi Kapsamında Üreticilerin Kullandıkları Bilgi Kaynakları. Tarım Ekonomisi Dergisi 11(1):41-49.

Turhan, Ş. (2005) Tarımda Sürdürülebilirlik ve Organik Tarım. Tarım Ekonomisi Dergisi 11(1):13-24.

Türer, H. (2019) Samsun İli Bafra İlçesinde Çeltik Üretiminde Toplam Masraf, İşgücü Gereksinimi ve İş Başarılarının Belirlenmesi. Yüksek Lisans Tezi, Ondokuz Mayıs Üniversitesi. 


\section{Çeltik Üreticilerinin Katıldıkları Tarımsal Yayım Yöntemlerinin Sürdürülebilir Tarım Algılama Düzeylerine Göre Değerlendirilmesi}

Yalçın, M., Boz, İ. (2007) Kumluca İlçesinde Seralarda Üreticilerin Kullandıkları Bilgi Kaynakları. Bahçe Dergisi 36(1):1-10.

Y1lmaz, H., Demircan, V., Gül, M. (2009) Üreticilerin Kimyasal Gübre Kullanımında Bilgi Kaynaklarının Belirlenmesi ve Tarımsal Yayım Açısından Değerlendirilmesi. Süleyman Demirel Üniversitesi Ziraat Fakültesi Dergisi 4(11):31-44.

Y1lmaz, H. Örmeci Kart, MC., Demircan, V. (2016) Economic Analysis of Pesticide Use in Wheat Production for Sustainable Rural Development. Proceedings of the 17. International Scientific Conference on Economic Science for Rural Development, Latvia University of Agriculture Faculty of Economics and Social Development, 21-22 April 2016, No 42, pp. 295-302, Jelgava, Latvia.

Yilmaz, H. (2018) Economic and environmental analysis of pesticide use for sustainable barley (Hordeum vulgare L.) production in Turkey. Revista de la Facultad de Agronomía de la Universidad del Zulia (LUZ) 35: 85-107.

Yurdakoş, E. (2009) Türkiye'nin Avrupa Birliği Çeltik Ortak Piyasa Düzenine Uyumunun Piyasalara ve Samsun İli Çeltik İşletmelerine Etkilerinin Araştırılması. Yüksek Lisans Tezi, Ondokuz Mayıs Üniversitesi. 
Çeltik Üreticilerinin Katıldıkları Tarımsal Yayım Yöntemlerinin Sürdürülebilir Tarım Algılama Düzeylerine Göre Değerlendirilmesi 